\title{
Reuse Waste Material and Carbon Dioxide Emissions to Save Energy and Approach Sustainable Lightweight Portable Shelters
}

\author{
Ammar ALKHALIDI ${ }^{1 *}$, Yara Nidal ZAYTOUN ${ }^{2}$ \\ ${ }^{1,2}$ Energy Engineering Department, German Jordanian University, Amman 11180, Jordan
}

\begin{abstract}
Despite their great significance, lightweight structures have poor thermal inertia. In order to enhance the thermal comfort inside such buildings, architects need lightweight thermal storage. In this paper a model was used to experimentally investigate Heating Load profiles in lightweight shelters. The profiles were created for the climate in Jordan, then simulated for other climate zones. The proposed design concept was used to create a replacement for a thermal mass in lightweight structures such as shelters; by combining passive solar gain with energy storage embodied within the shelter floor (thermal-floor) to absorb solar radiation. This shelter design decreased the Heating Load during the winter season by acting as heat storage that releases energy at night time after being exposed to solar radiation during the day. The passive design depends on shading elements and overhangs shades to control solar gain during different seasons to prevent overheating during the summer. An experimental investigation of this model was performed to validate the simulation results. Validated simulation results showed that the designed thermal-floor is $25 \%$ of the total shelter's floor area, which was crucial for obtaining favourable results. With $\mathrm{CO}_{2}$ as a thermal mass, heat load was reduced up to $68 \%$ compared to a $20 \mathrm{~cm}$ concrete slab floor. The use of this thermal storage material yielded a reduction in annual heating demand by $85 \mathrm{kWh} / \mathrm{m}^{2}$.
\end{abstract}

Keywords - Comfort Zone; Jordan weather sustainability, lightweight shelter; thermal mass.

\begin{tabular}{|lll}
\hline Nomenclature & \\
ASHRAE & American Society of Heating, Refrigerating and Air-Conditioning Engineers & \\
$\mathrm{BIM}$ & Building Information Modelling & \\
$\mathrm{CO}_{2}$ & Carbon dioxide & $\mathrm{J} / \mathrm{kg} \cdot{ }^{\circ} \mathrm{C}$ \\
$C p$ & Heat capacity & $\mathrm{kWh}$ \\
$E h$ & Heating Energy demand & \\
$\mathrm{GHG}$ & Greenhouse gases & \\
$H D D$ & Heating Degree Days & \\
$\mathrm{HDPE}$ & High-density polyether & \\
$\mathrm{PCM}$ & Phase change material & $\mathrm{W}$ \\
$\mathrm{PMJ}$ & Petroleum Jelly & \\
$Q$ & Heat Load &
\end{tabular}

* Corresponding author.

E-mail address: ammar.alkhalidi@gju.edu.jo

(C2020 Ammar Alkhalidi, Yara Nidal Zaytoun.

This is an open access article licensed under the Creative Commons Attribution License (http://creativecommons.org/

licenses/by/4.0), in the manner agreed with Sciendo. 


\begin{tabular}{|llc|}
\hline$U$ & Fabric U-value & $\mathrm{W} / \mathrm{m}^{2} \cdot \mathrm{K}$ \\
$U^{,}$ & Overall building heat loss coefficient & $\mathrm{kWK}$ \\
Subfloor & A floor elevated and separated from the ground by an air gap & \\
$\rho$ & Density & $\mathrm{kg} / \mathrm{m}^{3}$ \\
$\eta$ & Overall seasonal heating system efficiency & \\
\hline
\end{tabular}

\section{INTRODUCTION}

Buildings are an integral part of all civilised societies, yet they are the largest source of pollution. Researchers showed that a small sustainable change in buildings and employing energy-efficient techniques [1] have a great effect on greenhouse gases (GHG) emissions and global warming. Residential and commercial buildings' energy consumption on average increases by $1.5 \%$ annually, and in 2016 buildings consumed $20.1 \%$ of the global energy. The wider share of this Heating Load is related to heating, ventilation, and air-conditioning (HVAC) [2]. Buildings in Jordan accounted for $23 \%$ of the total energy consumption in 2003 and are expected to rise in 2010 by $30 \%$ [3]. While efforts to limit the emissions of greenhouse gases are considered in developed countries, economic growth in developing countries is causing an increase in emissions; these emissions must be reduced by utilising climate-friendly technologies [4].

Lightweight buildings, such as shelters, have great significance for such countries as Jordan, which is experiencing a refugee crisis [19]. Moreover, climate change is expected to bring a significant pattern of refugee migration among the developing countries, this migration is called environmental refugees [20]. This sustainable shelter provides an adaptation technique for such crises. However, a lightweight building has low thermal inertia and its indoor temperature is affected vastly by the outdoor ambient.

A thermal mass is comprised of thermal materials that have the ability to absorb the heat, and to store it to be released later. A thermal mass includes the envelope of buildings, internal walls, furniture, etc. [5]. Thermal masses in buildings store the heat, which transfers from the hot side to the cold side. When thermal masses absorb and store the heat, they lead to temperature lag between internal and external spaces. When the air around a thermal mass cools down, the heat stored within it will be released [6]. A thermal mass determines the capability of the building to store the heat energy, whether sensible or latent. Therefore, a thermal mass has a great effect on indoor temperatures, power consumption, and residential comfort. Parameters that affect the performance of thermal mass were concluded by [5], including the heat storage capacity, the surface area of thermal storage, the diurnal heat capacity and the layer thickness [5].

Some architecture designers think that the presence of thermal mass is good, but when it is used inappropriately, it could increase the energy consumption instead of decreasing it. [7] had studied the influence of thermal masses in 2017 for a hot climate that experiences large variations in the diurnal temperature; the results showed that savings in the heating load are possible [7]. On the other hand, a thermal mass for cold climates, where heating is a dominant distress, demonstrated that a thermal mass is a drawback; altering the design goal in cold climates to reduce thermal mass and raise thermal insulation [2]. Buildings with a great amount of thermal mass will have extended preheating or precooling periods [8].

A thermal mass has multiple types that include but not limited to bricks, concrete, concrete blocks, and earth; those all have a high density and heat capacitance; thus, they are considered 
good thermal materials for buildings. Carbon dioxide $\left(\mathrm{CO}_{2}\right)$ emissions in construction materials is an important issue, research indicates that the indirect polluting emission occurring outside the construction site holds energy intensity higher than direct emissions. Steel reinforcement and cement are good examples of indirect emissions that happen during the manufacturing process [9]. However, some phase change materials (PCMs) have thermal mass properties without the weight or thickness constraints like in concrete. PCMs absorb then release energy by melting or solidifying; including plasterboard, screed or paints and frequently include microcapsules of wax [10]. The location of thermal mass is of the utmost importance, for example, water tanks location could be employed to protect western walls since they will absorb solar radiation during the afternoon.

A thermal mass must be located in a way to counter passive solar gains. Otherwise it will absorb the room's heat in winter, making it colder. The best location for a thermal mass in winter is on the floors and walls that receive direct solar gain. Glass facade should be northfacing, if not, south-facing windows must be shaded. The shading must be designed to protect the thermal mass from the summer sun, at the same time it must allow winter sun to cross the space [11]. In summer, the thermal mass must be in well-ventilated rooms. Ventilation is needed to remove the heat absorbed during a summer day [12], otherwise it will continue to accumulate heat creating an oven effect throughout several hot days. Ventilation is better executed at night [13] and is called night purge [6].

A thermal mass, according to some literature, applied only to sensible heat storage. Yet, when PCMs are utilized as latent heat storage, they can raise a building's thermal inertia without using great amounts of material; hence a latent heat storage embodied within a lightweight element can perform like heavyweight elements in constructions [2]. One of the technologies that were developed to enhance the efficiency of renewable energy sources is thermal energy storage (TES) [8]. Sensible heat storage occurs in the form of temperature change in the medium such as water, oil, rock beds, air, concrete, bricks, and sand. Latent heat storage occurs when the heat is utilized form the phase transition like in PCMs. A high thermal capacity in a shaded and an insulated building can lower its indoor maximum temperature by $35-45 \%$ compared to the outdoor temperature when the building is unventilated [14]. In 2017, a thermal mass resulted in 10-15\% energy savings for heating by mixing various types of thermal materials into the envelope of the building [15].

A thermal mass, according to some literature, applied only to sensible heat storage. Yet, when PCMs are utilised as latent heat storage, they can raise the thermal inertia of the building without using great amounts of material; hence latent heat storage embodied within a lightweight element can perform like heavyweight elements in constructions [2]. One of the technologies that were developed to enhance the efficiency of renewable energy sources is thermal energy storage (TES) [8]. Sensible heat storage occurs in the form of temperature change in the medium such as water, oil, rock beds, air, concrete, bricks, and sand. Latent heat storage occurs when the heat is absorbed by the phase transition like in PCMs. High thermal capacity in a shaded and an insulated building can lower its indoor maximum temperature by $35-45 \%$ compared to the outdoor temperature when the building is unventilated [14]. In 2017, a thermal mass resulted in 10-15\% energy savings for heating by mixing various types of thermal materials into the envelope of the building [15]. Building envelops and international certificates for the building were reviewed by [16], [17].

Previous studies had investigated the performance of thermal mass for residential or commercial buildings. Thermal mass needs the combination of solar energy with thermal energy storage [8], which had not been tested in shelters yet. There is a deficit in research focusing on thermal mass performance in some climate zones such as low temperate and cold 
zones [7]. Energy efficiency in the lightweight building was investigated by [2], [18], [19]. Thermal mass in the building was investigated by [6], [8], [18]. Up to the author's knowledge, thermal mass in the lightweight building was never investigated.

The goal of this paper is to investigate the possibility of reusing lightweight material; hence, PCMs and carbon dioxide; to replace traditional thermal mass inside lightweight structures, shelter, without increasing the structure weight significantly. Normally, shelters are constructed from a steel frame and a light insulation material and do not contain thermal masses. The thermal mass' material is usually heavy and can increase the shelter weight significantly, which limits its ability to be transported easily. This was achieved by investigating different materials that can perform as thermal mass for lightweight portable structures such as shelters. This paper investigates the effect of the thermal storage in the floor on the heating load required and heating demand as well. Since the thermal storage in the floor (thermal-floor) will contain materials such as carbon dioxide and petroleum jelly to dedicate polluting emissions and serve energy efficiency in lightweight structures.

\section{Methodology}

The thermal mass material in a lightweight structure - prefabricated shelter - was investigated experimentally to determine the best performing material during winter season. Experimental data were used to validate results found by HvacLoadExplorer software, the cooling/Heating Load calculation software that accompanies the Heating, Ventilating, and Air Conditioning [20]. This software was used to investigate the heating load of the shelter (Fig. 5 - Fig. 10) utilising the material with the best overall performance based on the experimental investigation.

The shelter design adopted for the experimental investigation is shown in Fig. 1. The thermal mass material was enclosed in the area labelled thermal-floor (Fig. 2). Materials with high thermal capacity and low density were expected to emulate the best thermal mass performance. Therefore, they were considered to be the optimal candidate for a portable shelter without increasing its weight.

Thermal floor experiment was done by testing a real model designed as shown in Fig. 1. The model was placed in a room cooled to $20^{\circ} \mathrm{C}$ in order to create a controlled environment to apply the concept in a cold ambient; it should be mentioned that this experiment was done during summer months of 2017, July and August.

Thermocouples were used to measure the temperature; the readings were taken from a multi-meter. A SEAWARD radiation meter was also used to set the desired radiation of $500 \mathrm{~W} / \mathrm{m}^{2}$ for a period of five hours, which resembles winter sun hours in Amman, Jordan [21]. Thereafter, the temperature inside the shelter model, as well as the floor, for each tested material was measured using thermocouple sensors located in the center of the shelter's inner space also on the floor. Thermocouples were located according to methods of sensor distribution described by [22] and [23]. The results were compared to several floor materials such as tiles, concrete and metal decking that are common for caravans. 

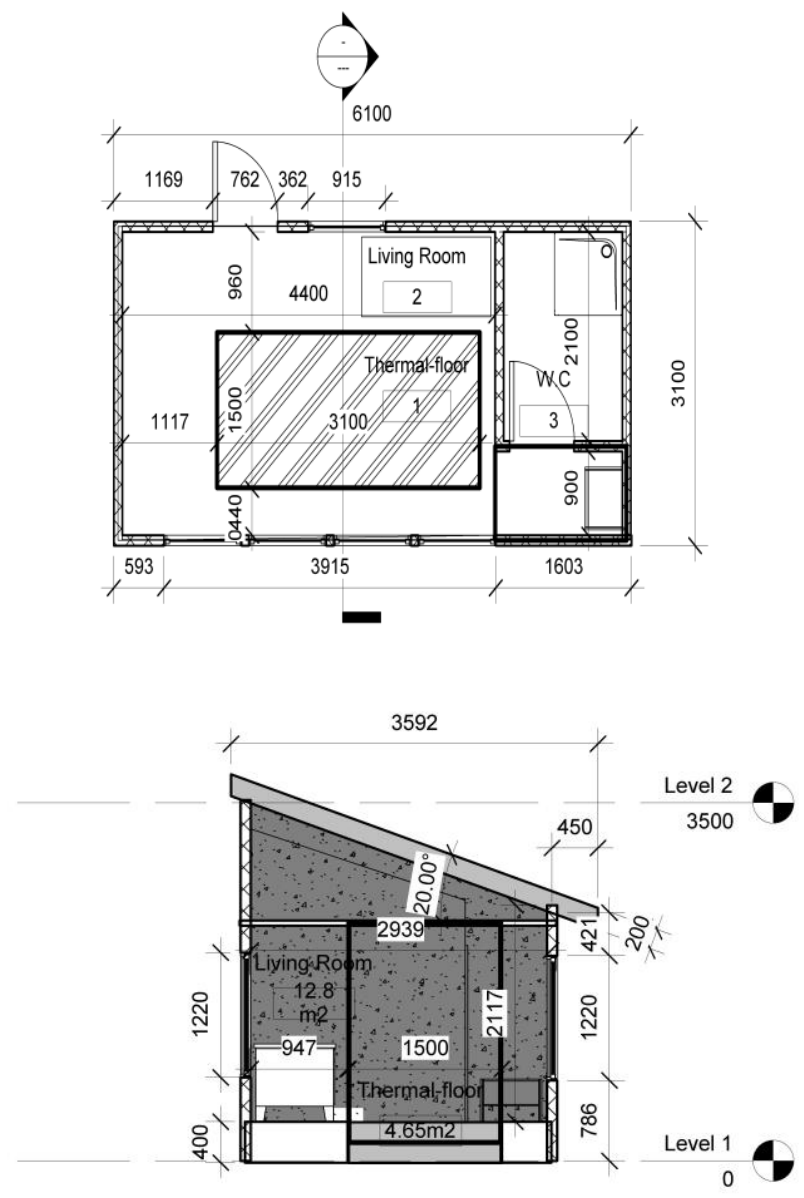

Fig. 1. Sustainable passive shelter design layout with dimensions, floorplan + section (all dimensions in $\mathrm{mm}$ ).
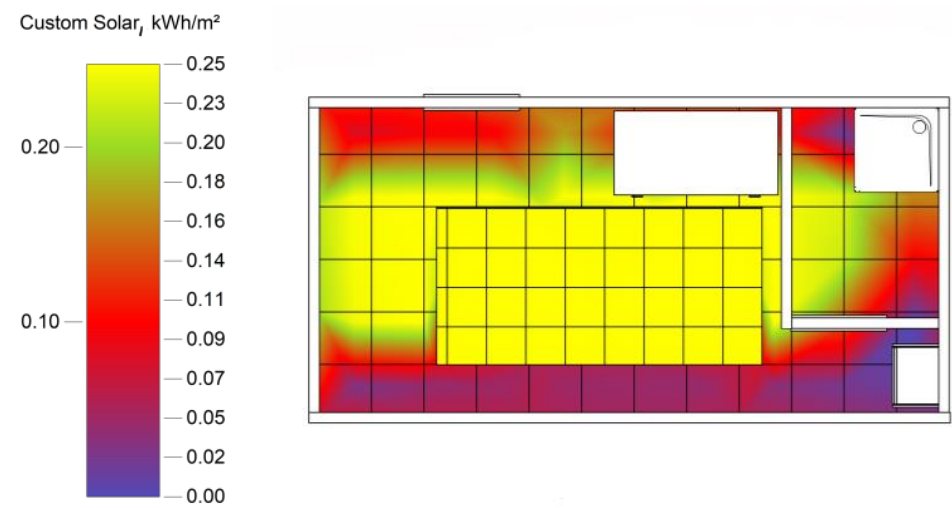

Fig. 2. Peak solar insolation subjected to the shelter floor, peak insolation for one day of December, Amman, Jordan. 
The design concept depends on a passive energy gain, combining large southern windows with thermal energy storage embodied within the floor reusing materials such as petroleum jelly and $\mathrm{CO}_{2}$ to replace conventional thermal mass. This mechanism is validated during winter since the southern windows are shaded by an overhanging shade (Fig. 1), that allows low winter sun to penetrate the space and blocks summer sun that has a high angle, so the thermal-floor is blocked from summer radiation. In the summertime, the indoor thermal comfort was maintained through natural ventilation, which helps to carry the heat away. In addition to that, the shelter walls are completely insulated using polyether foam, and all the windows are double-glazed with low emissivity that has a high $R$-value up to $2.7 \mathrm{~K} \cdot \mathrm{m}^{2} / \mathrm{W}$. Air Conditioning split unit is proposed to cool the space during hot days of summer. However, using energy-efficient measures such as overhang shading and natural ventilation, the cooling load will be decreased to the minimum, causing the air conditioning to work fewer hours more efficiently.

In winter time, large southern windows to capture solar radiation during the day were used. Then a part of the floor was filled with a PCM material, as listed in Table 1, to work as heat storage and to help decrease the heating load. Finally, high thermal insulation using expanded polystyrene with $\mathrm{U}$-value $0.13 \mathrm{~W} / \mathrm{m}^{2} \cdot \mathrm{K}$ prevents major heat losses from the inner space, which will support the work of the air conditioning to provide heating up to the thermal comfort levels with less energy demand; the AC unit is to be fed from PV cells.

Materials were chosen also to have low density $\left(\mathrm{kg} / \mathrm{m}^{3}\right)$, so it can perform as a thermal mass without increasing the weight of the shelter. The thermal-floor block area is $4.8 \mathrm{~m}^{2}$ with a $15 \mathrm{~cm}$ depth (volume $=0.72 \mathrm{~m}^{3}$ ), so the density will dominate the weight of this part when materials are compared in Table 1.

TABLE 1. EXPERIMENT MATERIALS PROPERTIES [10], [24]

\begin{tabular}{llll}
\hline Material & $\begin{array}{l}\text { Heat capacity, } \\
\mathbf{J} /(\mathbf{k g} \cdot \mathbf{K})\end{array}$ & Density, $\mathbf{g} \mathbf{c m}^{\mathbf{3}}$ & $\begin{array}{l}\text { Melting Point, } \\
{ }^{\circ} \mathbf{C}\end{array}$ \\
\hline $\begin{array}{l}\text { Vaseline-Petroleum } \\
\text { Jelly (PCM) }\end{array}$ & $2.14-2.90$ & $0.79-0.85$ & 36 \\
\hline $\begin{array}{l}\text { Paraffin wax } \\
\text { (PCM) }\end{array}$ & $2.14-2.90$ & 0.896092 & $\mathbf{4 6}$ \\
\hline $\begin{array}{l}\text { Graphite } \\
\text { Wax (PCM) }\end{array}$ & 0.71 & $2.09-2.23$ & - \\
\hline Water (PCM) & 3.43 & 0.9 & 37 \\
\hline $\begin{array}{l}\text { HDPE (high-density } \\
\text { polyethylene) }\end{array}$ & 4.184 & 1 & 0 \\
\hline \begin{tabular}{l} 
CO2 gas at 100 kPa \\
\hline
\end{tabular} & 840 & 0.93 & - \\
\hline
\end{tabular}

\section{RESULTS AND DISCUSSION}

\subsection{Thermal-floor effect on temperature}

The main goal of the experiment was to track the behaviour of the material when subjected to radiation of $500 \mathrm{~W} / \mathrm{m}^{2}$ for 5 hours, which is the solar radiation in winter in Amman. Sensors were placed inside the shelter space and it was tested under controlled conditions. Fig. 3 and Fig. 4 track the temperature variations for each material, separately, from the starting point when the radiation is on, then radiation goes off after 5 hours and tracking continues until the 
floor and the room cool down to room temperature. Low-density materials with high heat capacity $(C p)$, such as PCMs were examined and compared to tiles and concrete in Fig. 3. Additionally, materials that have bright colours such as Petroleum Jelly-Vaseline (PMJ) and paraffin wax were mixed with black paint to increase radiation absorption [6].

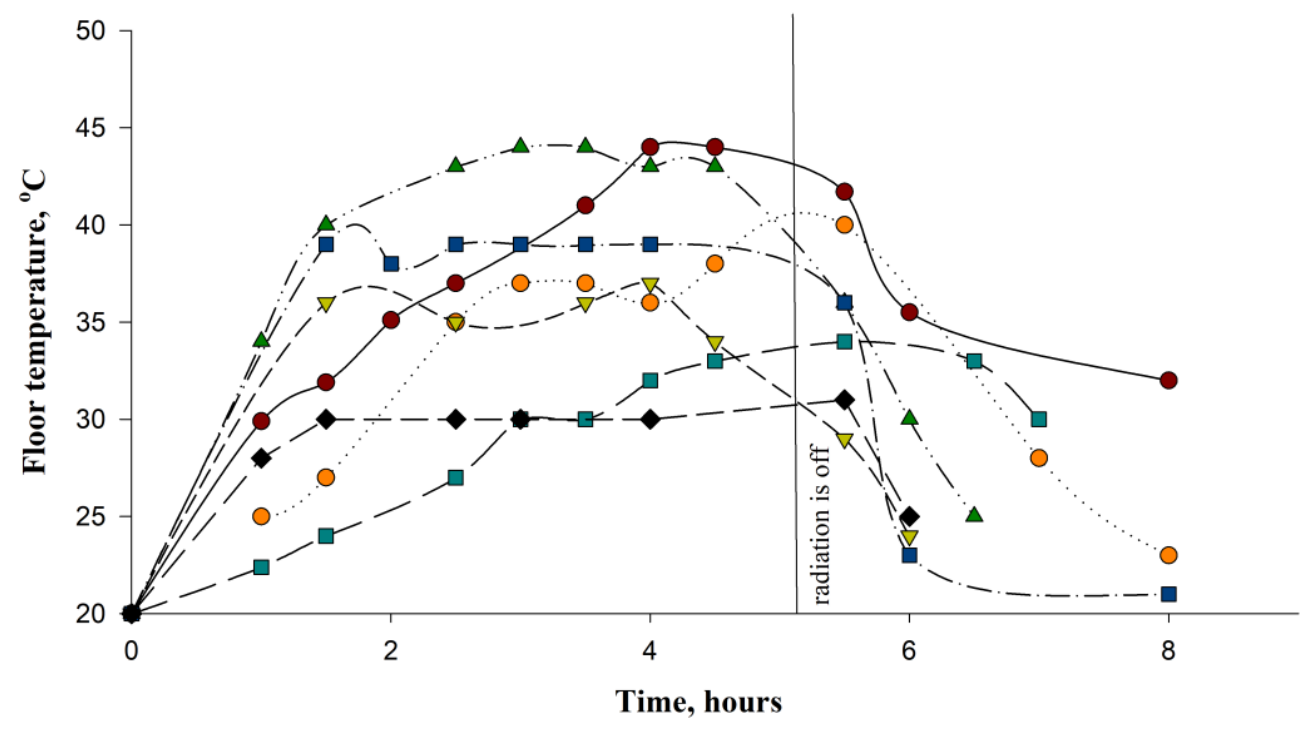

\begin{tabular}{|c|c|}
\hline $\begin{array}{l}\cdots \cdots \cdot 0 \cdots \cdots \\
--\rightarrow \nabla--- \\
-\cdots \rightarrow-\cdots \\
-\rightarrow-\square \\
--\square--\end{array}$ & $\begin{array}{l}\text { Petroleum jelly (Vaseline); coloured } \\
\text { Paraffin wax, colored with black paint } \\
\text { Graphite } \\
\text { HDPE } \\
\text { Water } \\
\text { Tiles, insulated white reflective surface } \\
\text { Concrete }\end{array}$ \\
\hline
\end{tabular}

Fig. 3. Experimentally obtained thermal-floor temperature using suggested materials to function as thermal mass, compared to concrete and tiles.

Minutes after the solar radiation was turned on, the initial floor temperature of all measured materials was approximately the same with an exception of insulated white tiles that were one degree higher. Finally, when the solar radiation was turned off, the floor's temperature dropped rapidly back to its initial temperature. When water was used as a thermal mass, the floor's temperature at the start of the solar radiation was low, in comparison to the rest of the materials, but once the solar radiation was off, water maintained a relatively high floor temperature for a little more than one hour. PMJ yielded the highest floor temperature during exposure to solar radiation and maintained the highest floor temperature over a few hours after the solar radiation stopped. HDPE was able to absorb heat from the solar radiation quickly, but it did not store much energy as evidenced by the rapid decrease in the floor's temperature just after the solar radiation stopped. The thermal floor's behaviour was reflected in the room's temperature detected experimentally; this effect can be seen clearly in Fig. 4. 


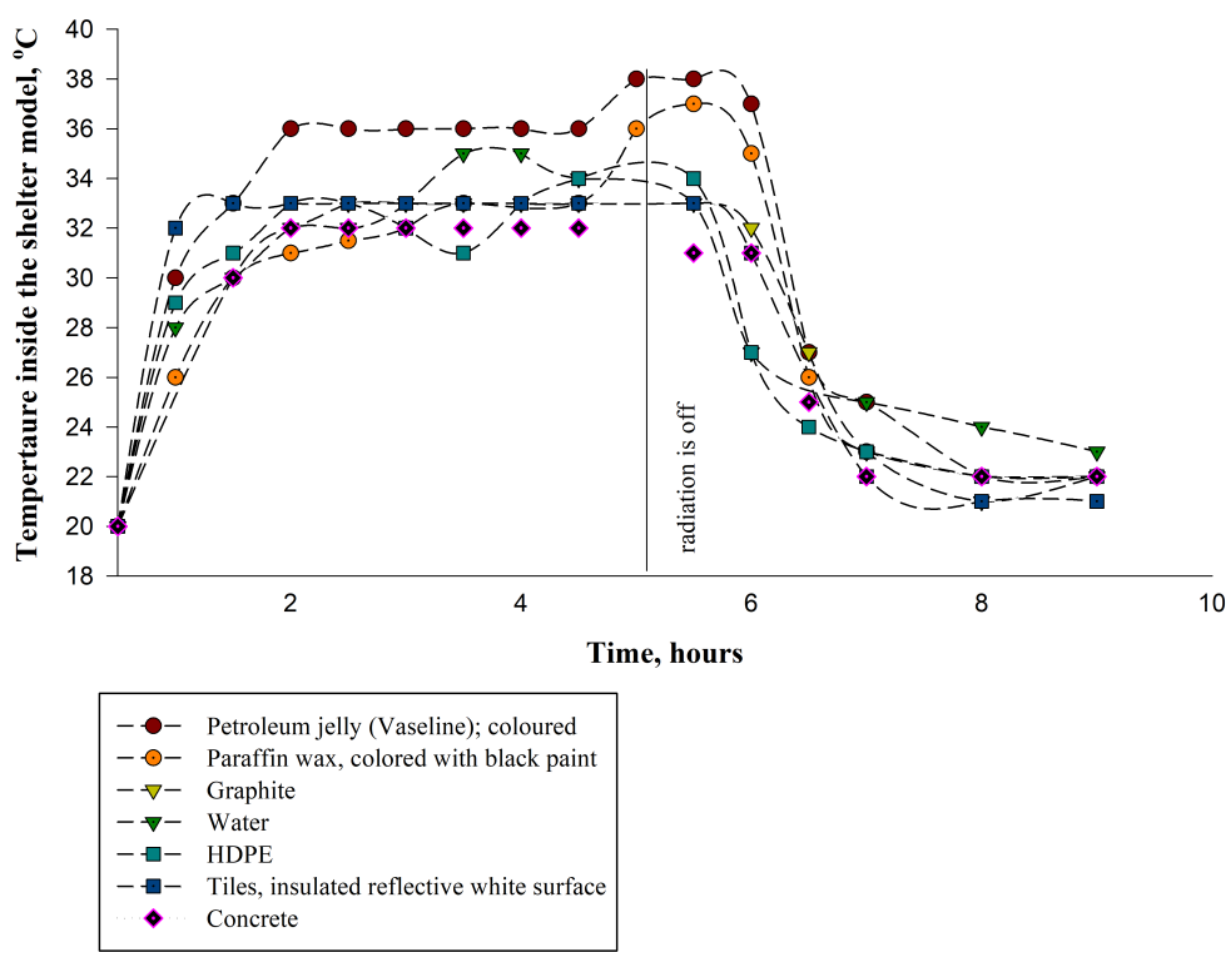

Fig. 4. The shelter model space temperature comparing thermal materials to concrete and tiles.

The installation of a thermal-floor into the shelter model was intended to capture energy from solar radiation in the winter season and heat the space (hence reduce heating load and energy demand for heating as well), while simultaneously store the energy and redeem it once the solar radiation ceases leading to a reduction in heat demand of the shelter. An additional measurement to the floor temperature is the space temperature of the shelter model, shown in Fig. 4, together they gave a better indication of the behaviour of the thermal-floor containing the thermal mass. PMJ yielded the highest space temperature while under solar radiation and relatively higher temperature once the solar radiation had stopped. HDPE had a similar profile to PMJ during and after solar radiation but its performance was weaker in comparison to PMJ especially when considering the space temperature from 1 to 4 hours. Concrete seems to need higher solar radiation; hence higher energy intensity to perform as an energy storage medium for the shelter model. Based on the measurements shown in Fig. 3 and Fig. 4 and given its low melting temperature and its ability to store the extra energy as latent heat then release it later, petroleum jelly PMJ mixed with black paint was selected as the thermal-floor material and will be used henceforth in this study.

\subsection{Validation}

Software analysis needs validation by experimental results before taking its results for granted to scientific researchers. HvacLoadExplorer was used by much previous research to conduct heating and cooling loads [25]-[27]. Simulation using HvacLoadExplorer depended 
on defining each building element according to its thermal condition. This software uses the heat balance method (HBM) for calculating cooling and Heating loads in buildings. For heating load calculations, it uses the winter data of one day of the coldest month for each location for the calculation. The climate data were extracted from the ASHRAE Handbook [28].

The controlled environment room helped to prevent serious airflow through the model, which can add the effects of convective heat transfer. Even though convection must always happen even in a slight amount, and this certainly affected the temperature measured inside the model. Shelter model edges were perfectly sealed with polyether foam insulation, though it will not prevent the thermal leakage from heat bridges especially within opening spots, such as windows and doors.

Temperature results from the experiment shown in Fig. 3 and Fig 4 were used to calculate heating load variations in Eq. (1); the result found was compared with results generated from the program in Fig. 5.

$$
Q=U \cdot A \cdot \Delta T
$$

where

$Q$ heating load;

$U \quad \mathrm{U}$-value of the material that indicates the ability of the material to conduct heat through it;

$A$ surface area of the shelter;

$\Delta T$ heating degrees needed for the inside of the shelter (taken from the experiment) to reach the comfort zone limit.

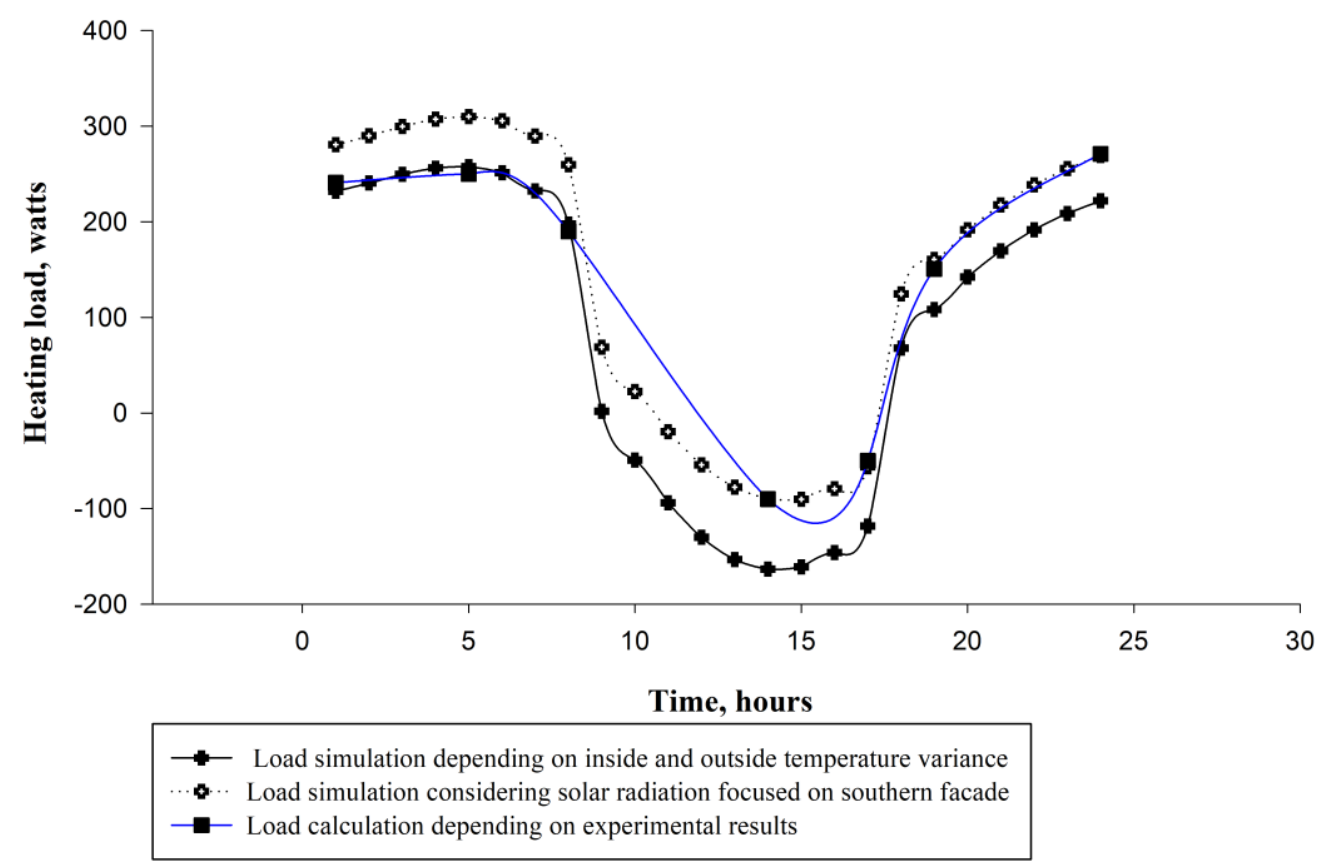

Fig. 5. Heating load value comparison between simulated and experimental calculations. 
The model's elements material, wall, floor, and windows were defined to match the material used in the tested model. The heating load found from the experimental work was compared to simulation results. The simulation was performed based on two techniques. The first simulation was based on solar irradiance; direct solar irradiance on the southern wall was measured during the experiment. The second simulation was temperature base; the reference temperature was of the southern wall, which was subjected to radiation. During the experiments, outside wall temperature was measured using Laser Infrared Thermometer. The temperature reading was used in software to run the simulation. The simulation results were 93.8-99.5\%, which is close to experimented values. Validation results are illustrated in Fig. 5; the error between both results had been calculated, and its range was between $0.17 \%$ and $6.8 \%$ and the simulation for the solar irradiance case was more accurate than the simulation depending on the temperature difference. Based on the comparison between the simulation and the experimental results, it was concluded that the simulation is valid and the simulation-based on solar irradiance is more accurate. Thus, it will be used for the further investigation.

To consider other factors of error propagation, first, the Vaseline was exposed to $500 \mathrm{~W} / \mathrm{m}^{2}$ radiations twice; the overall percent uncertainty was \pm 0.63 . Hence, the data between the two trials matched up to $92 \%$. The error was produced considering both instrumental uncertainties of the multi-meter that is \pm 0.5 . The total relative uncertainty ranges from $\pm 0.6-1.02$. The experimental values were conducted twice and the relative error for the whole value readings was from $0.07-0.2$. Finally, a sensitivity analysis was conducted to weight the effect of temperature error on heating load calculation, because the temperature was used to validate the load calculation software; as a result, the temperature will cause uncertainty of \pm 15.06 watts in the heating energy demand, which is $6.64 \%$ of the calculated value.

\subsection{Heating load for the shelter in different climate zones}

Heating Energy demand $E h$ and consumption $\left(\mathrm{kWh} / \mathrm{m}^{2}\right.$ per year) mean annual specific needs and consumptions per net heated area. A building is heating energy needs means the energy required to maintain indoor air conditions. So Heating Energy demand is based on the building's heat losses that are represented here by heating load profiles.

The monthly heating energy consumption can be calculated by:

$$
E h=\frac{U^{\prime} \cdot H D D \cdot 24}{\eta},
$$

where

Eh Heating Energy demand, kWh;

$H D D$ Heating Degree Days;

$\eta \quad$ overall seasonal heating system efficiency;

$U^{\prime} \quad$ overall building heat loss coefficient (kWK), given by:

$$
U^{\prime}=\frac{A \cdot U+\frac{1}{3} N V}{1000},
$$

where

$U \quad$ fabric $\mathrm{U}$-value, $\mathrm{W} / \mathrm{m}^{2} \cdot \mathrm{K}$;

A component area, $\mathrm{m}^{2}$;

$N \quad$ air infiltration rate in air changes per hour, $\mathrm{h}^{-1}$;

$V \quad$ volume of the space, $\mathrm{m}^{3}$. 
The numerical factor $1 / 3$ arises from typical values of density and specific heat of the air and the conversion to air changes per hour [29].

The thermal-floor effect on the heating load was simulated in the coldest month of the year considering a one-day heating load, which differs accordingly to the location of the shelter. The system setpoint for heating was $25^{\circ} \mathrm{C}$ to make sure that the lowest temperature inside the shelter was no less than $22.2^{\circ} \mathrm{C}$ to comply with the comfort zone defined by the American Society of Heating, Refrigerating and Air-Conditioning Engineers (ASHRAE) [30]. The shelter's model was also tested in different locations worldwide (Fig. 6) and implied good performances in temperate climates such as London, UK. Simulation results implied that in temperate regions thermal-floor would reduce the heating load by $16.7 \%$ due to winters cold and the cloudy skies most days.

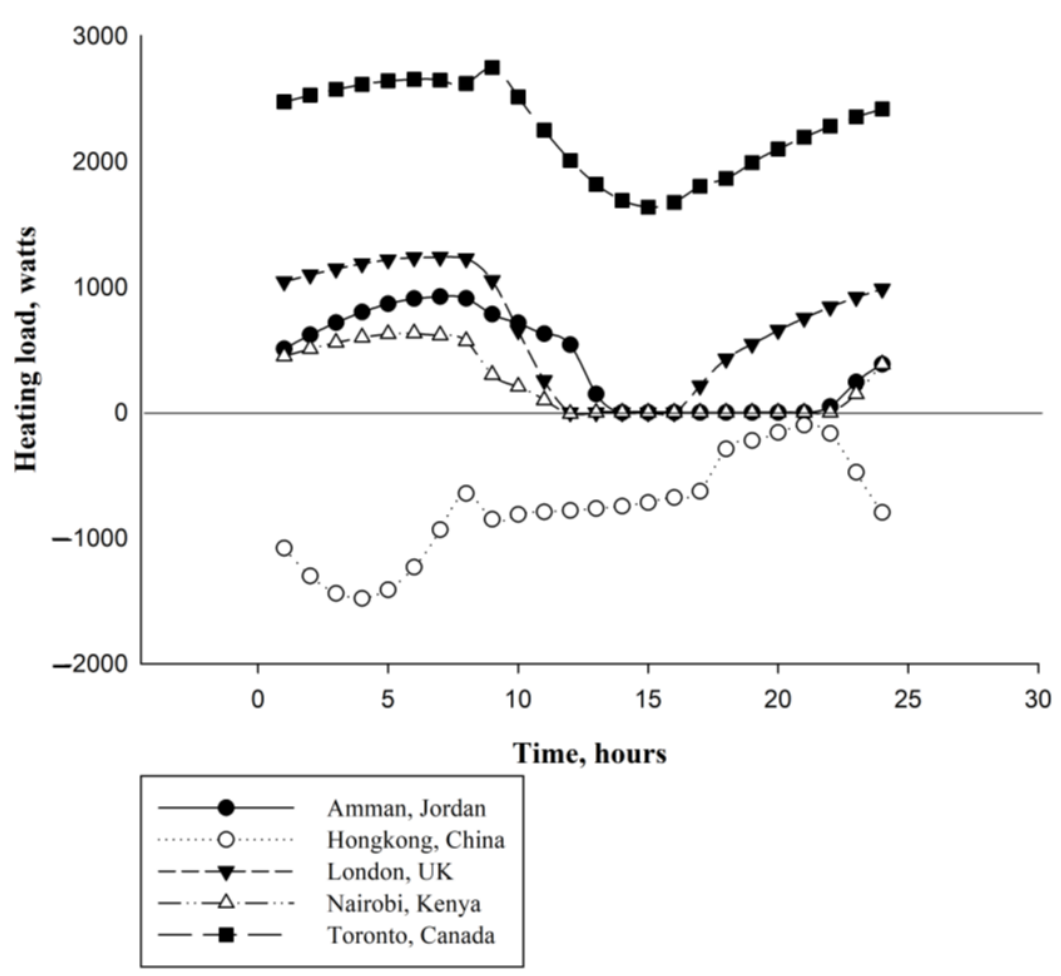

Fig. 6. Heating load for the shelter using PMJ material on the floor in different climate zones, each basic climate zone was represented by one city.

Temperate zones experience warm summers and cool winters in January at an average dry bulb temperature of $-1.2{ }^{\circ} \mathrm{C}$ and relative humidity of $75 \%$ [28], the use of thermal-floor reduced heating energy demand by $13 \mathrm{kWh} / \mathrm{m}^{2}$ per year. A thermal mass during the day is expected to absorb the heat from direct solar radiation, then release it at night time [7]. Thermal mass in cold zones caused discomfort if it was placed improperly according to previous research that agrees with our results. From literature it was found that when a lightweight single-family house was built using the concrete floor, the thermal behaviour 
became closer to heavyweight structure performance. For buildings with large window surfaces, $45 \%$ of the floor's area, the heating load was reduced by $15 \%$ [2].

A thermal-floor does not work efficiently in Polar Regions, the simulation was done for Toronto Canada, for January at an average dry bulb temperature of $-5.6{ }^{\circ} \mathrm{C}$ and relative humidity of $60 \%$ [24]. Similar to what was reported in previous studies that for cold regions sustainable lightweight buildings depend on high insulation to be used in the structures [7], [15], this could be attributed to the very low temperature and low solar radiation angles, with overcast sky most days.

Arid climates, such as in Amman, Jordan, are the best zones for a thermal-floor with high solar insolation and cold winters. $\mathrm{PMJ}$ and $\mathrm{CO}_{2}$ thermal-floors could reduce the heating load by $40-50 \%$ (Fig. 6) because it has large diurnal temperature ranges between day and night. Yet, for the tropical hot humid climate with warm winters, a thermal-floor would cause overheating, because the thermal-floor stores heat during the day and are not ventilated creating an oven effect over many hot days.

\subsection{Heating load and energy demand for the shelter in Amman, Jordan}

The shelter's model was designed for Amman, Jordan, as an example of subtropics (arid) climatic regions. Subtropics regions experience hot spells and significant temperature differences between daytime and night-time. Jordan's daytime temperatures are beyond comfort zone yet at night time the temperature drops below the range of comfort zone. A thermal mass is expected to be an appropriate addition in the arid regions.

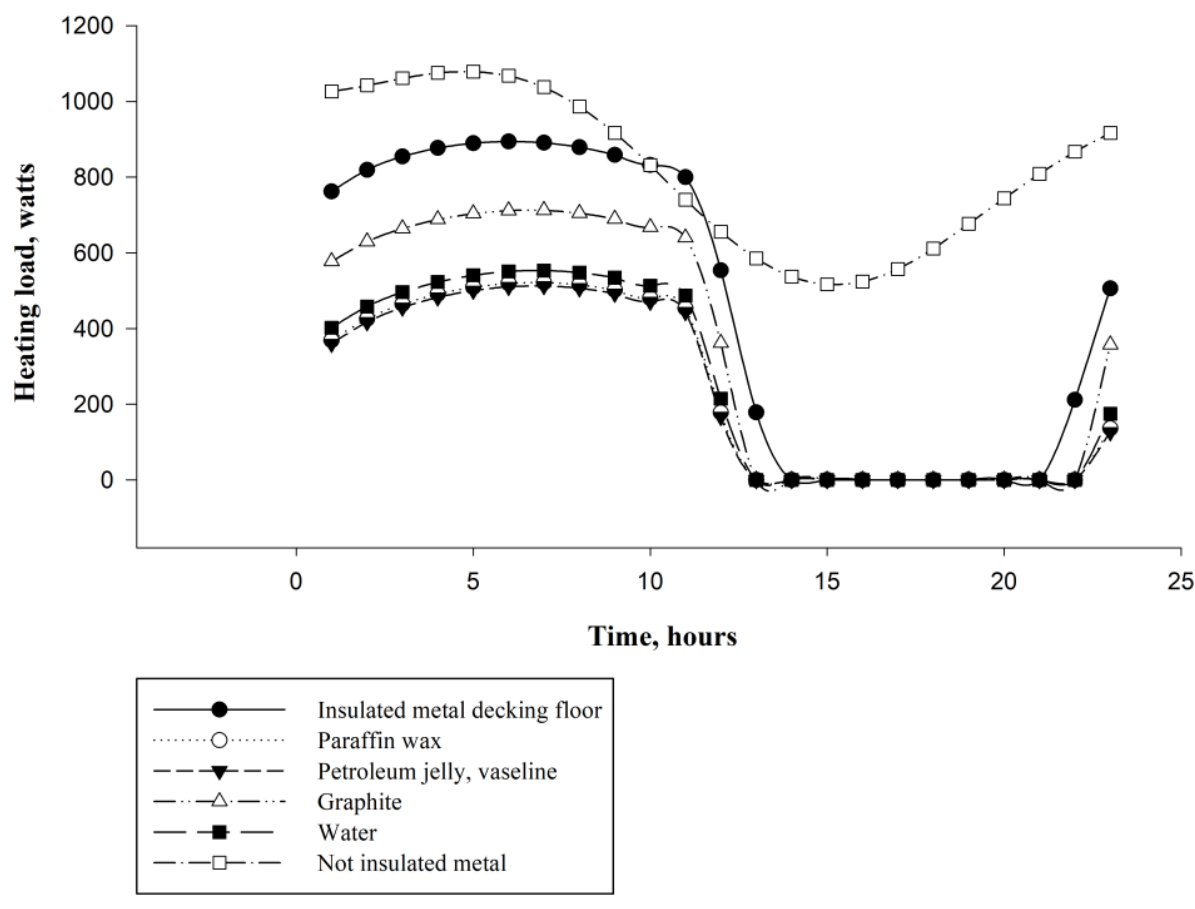

Fig. 7. Heating load of a shelter in Amman, Jordan, using different materials in the thermal-floor. 
The shelter's heat storage (thermal-floor) performance was investigated in Amman using HvacLoadExplorer, which estimated the hourly heating load in Watts for the day of 21 of January at an average temperature of $6.6^{\circ} \mathrm{C}$ and relative humidity of $83 \%$ [25]. The simulation was performed for two cases. The first case was performed with a metal floor with no insulation simulated, and most of the time heating load was in the range of 500-1000 W, as shown in Fig. 7. The insulated metal floor in the second case showed better performance than the first case but it was less efficient than using other materials on the floor as thermal mass.

In a shelter designed with $4.5 \mathrm{~m}^{2}$ thermal-floor, $40 \%$ window to wall ratio PCMs reduced the heating load by nearly $22 \mathrm{~W} / \mathrm{m}^{2}$ compared to the metal floor. Essentially, if the shelter was not thermally insulated none of the above results would have been achieved. The results indicated that using paraffin, PMJ, or water as thermal-floor, reduced the Heating demand by $45 \mathrm{~W} / \mathrm{m}^{2}$ compared to a metal floor that would reduce the annual heating energy by $32 \mathrm{kWh} / \mathrm{m}^{2}$.

\subsection{Carbon dioxide in the thermal-floor}

$\mathrm{CO}_{2}$ is a well-known thermal storage material in concentrated solar tower technology for renewable energy for it has a high heat capacity when pressurized and low density in the gaseous state, $1.78 \mathrm{~kg} / \mathrm{m}^{3}$ at room temperature [31]. $\mathrm{CO}_{2}$ in three different forms, gas at $100 \mathrm{kPa}$, pressurized liquid, and pressurized gas, were examined as a thermal-floor and the results are shown in Fig. 8.

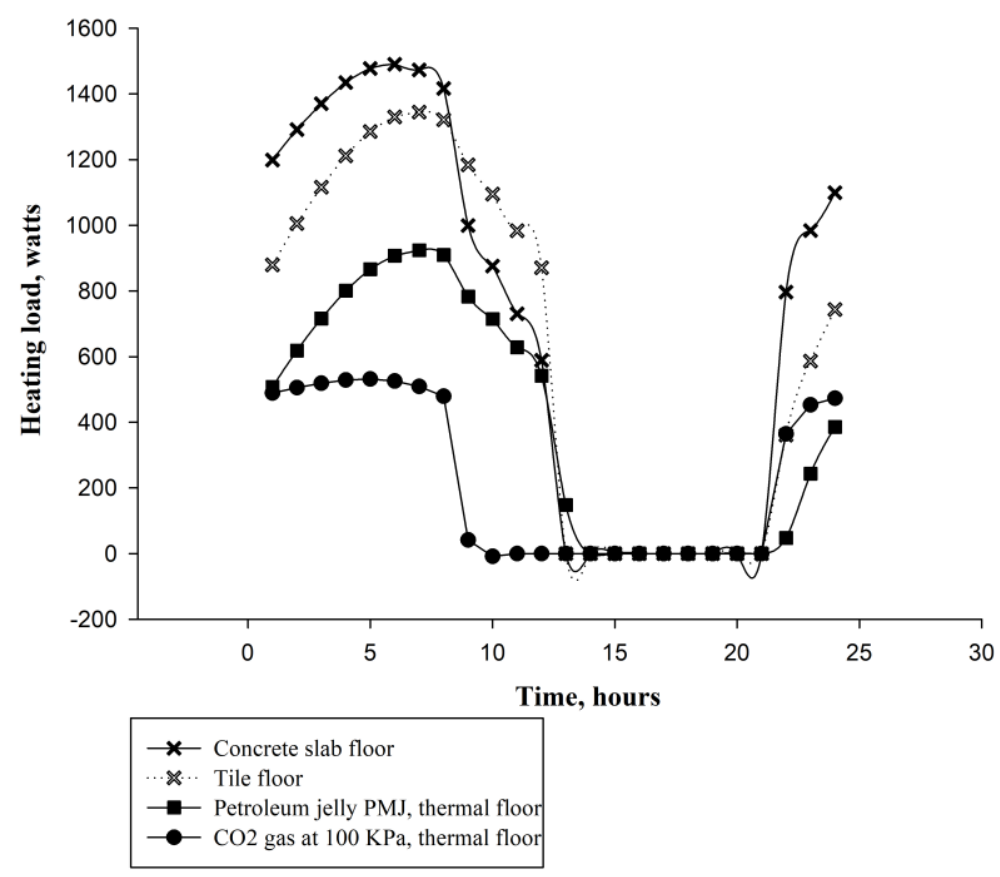

Fig. 8. Comparison of heating load for a shelter in Amman, Jordan between $\mathrm{CO}_{2}$ and PMJ thermal-floors; Shelter design with $4.5 \mathrm{~m}^{2}$ thermal-floor ( $25 \%$ of the floor area), $40 \%$ window to wall ratio. 
Saturated $\mathrm{CO}_{2}$ liquid reduced heating load from 30-50\% compared to tiles, yet saturated vapor has $241 \mathrm{~kg} / \mathrm{m}^{3}$ density, and saturated liquid has $714 \mathrm{~kg} / \mathrm{m}^{3}$. Both have density less than PMJ $840 \mathrm{~kg} / \mathrm{m}^{3}$.

$\mathrm{CO}_{2}$ and PMJ were also compared, as shown in Fig. 8, to tiles and concrete, which are the most common surfaces for floor construction worldwide. $\mathrm{CO}_{2}$ performed better than $\mathrm{PMJ}$ in the shelter. The thermal-floor weighed $150 \mathrm{~kg}$ when saturated $\mathrm{CO}_{2}$ vapor was used, $1.09 \mathrm{~kg}$ is the weight of $\mathrm{CO}_{2}$ gas, and $149 \mathrm{~kg}$ is the weight of the container; while $529 \mathrm{~kg}$ of PMJ was needed to achieve comparable performance. Therefore, the $\mathrm{CO}_{2}$ gas effect on the heating load was very close to that of PMJ, but with around $100 \mathrm{~kg}$ less weight.

\subsection{Thermal-floor position and area effect on heating demand}

The thermal mass is usually a wall or many walls working together, in this study, PMJ and concrete were tested as a wall and as a floor; both materials worked more efficiently as a floor and reduced Heating demand by 20-30\% compared to the same materials used in a wall. Different thermal-floor ratios were simulated for heating demand in the shelter model. If the whole floor were covered with PMJ instead of $25 \%$ of the floor, it would cause a slight reduction in heating demand by $4 \mathrm{kWh} / \mathrm{m}^{2}$ per year. A previous study demonstrated that the relationship between the amount of mass in the space and the ambient air temperature diurnal variation in the same space was an exponential relationship [32].

\subsection{Subfloor}

The floor can be designed in two different ways. In the first type the floor is directly connected to the ground, and so is affected by the ground temperature and the second type considers the floor is suspended (subfloor); such as walls, the subfloor is elevated and separated from the ground by an air gap. Both designs for subfloor were simulated for Amman, Jordan weather and results are shown in Fig. 9.

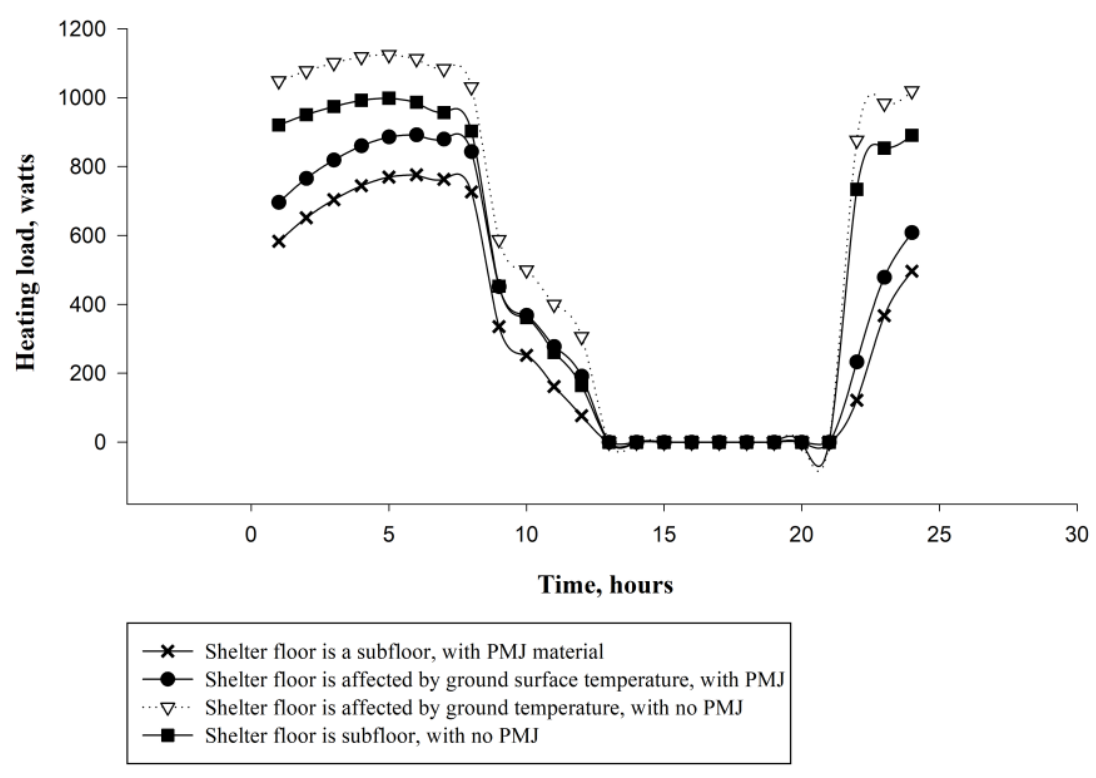

Fig. 9. Heating load value comparing subfloor and on a ground slab, Amman, Jordan. 
For a shelter design with $4.5 \mathrm{~m}^{2}$ thermal-floor of PMJ, $40 \%$ window to wall ratio, the results in Fig. 9 show that when the shelter's floor is built on the ground it would lose some heat to the ground below the floor. Based on that the heating load was higher for shelter with a floor connected to the ground as compared to the subfloor design.

\subsection{Window to wall ratio effect on Heating load}

A passive design depends on combining a thermal mass and a solar heat gain by employing large south-facing windows. The window to wall ratio is a very important concept in passive heating, so the simulation of a different window to wall ratios was carried out. For a room that has insulated walls and floor, increasing the window area to wall area ratio from 20 $80 \%$ led to only $8 \%$ heating load reduction $\left(5 \mathrm{kWh} / \mathrm{m}^{2}\right.$ per year). Yet when it was combined with the thermal-floor (100\% of the floor covered with PMJ), increasing the window area to wall area ratio from $20-80 \%$, reduced the annual Heating demand from 27 to $7 \mathrm{kWh} / \mathrm{m}^{2}(500$ $100 \mathrm{~W}$ ) as indicated in Fig. 10.

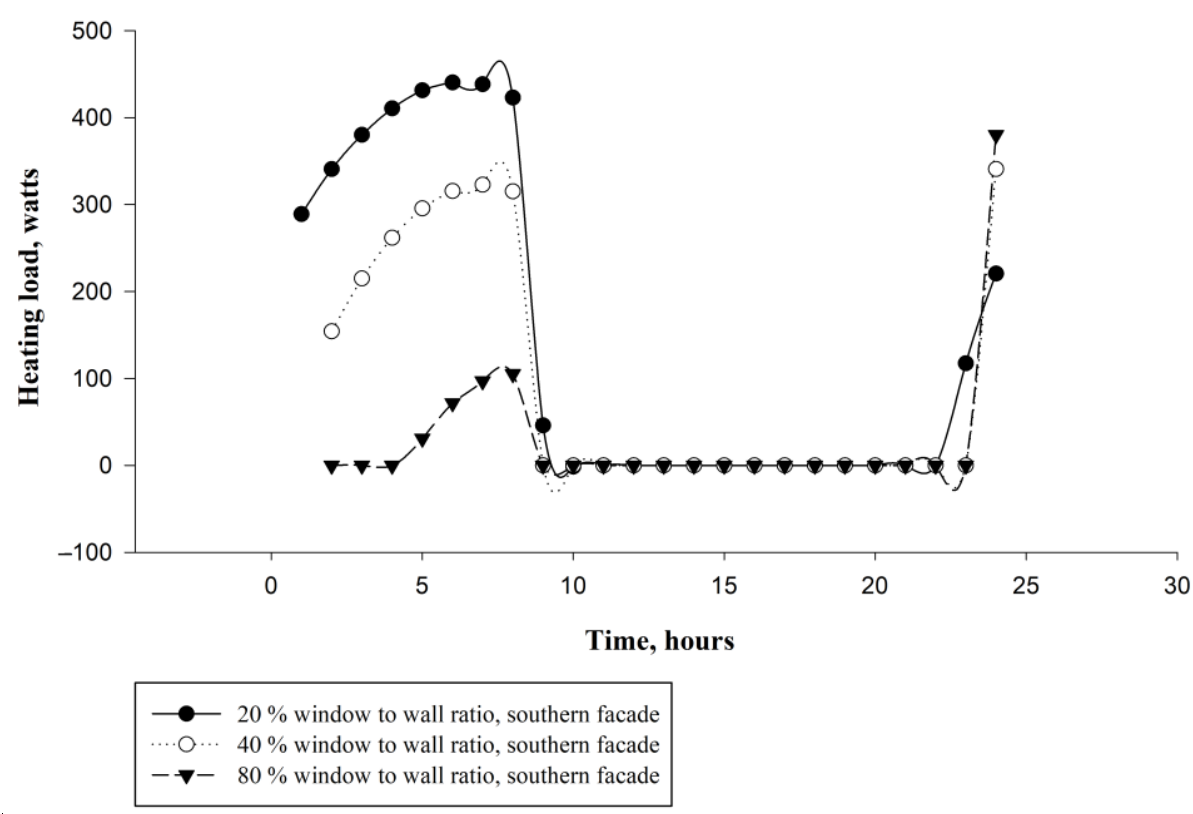

Fig. 10. Heating load profile for the different window to wall ratios for PMJ thermal-floor in Amman, Jordan.

This shelter design had a $40 \%$ window to wall ratio because in summer a large glazing facade is not convenient for all climates; it can be very suitable for the temperate zone with long winters and no major seasonal variations, but not suitable for other climate zones. Jordan is a subtropics (arid) climate it has cold winters but hot summers, so large windows would cause major heat gains and high energy demand for cooling in the summer. 


\section{4. $\mathrm{CO}_{2}$ THERMAL-FLOOR ENVIRONMENTAL IMPACT}

Since the goal of this study is to use a thermal-floor concept by employing recycled or reusable wasted products, it will help to save energy used for disposal, also it will help to create a new track for material residuals rather than dumbing products in the environment. Nearly $670 \mathrm{~kg}$ of $\mathrm{CO}_{2}$ equivalents are generated to produce $453.6 \mathrm{~kg}$ of HDPE. $79 \%$ of the greenhouse gas emissions are associated with fuel and $21 \%$ are related to manufacturing processes [33].

$\mathrm{CO}_{2}$ is one of the nontoxic and non-flammable working fluids that has good heat transfer characteristics. $\mathrm{CO}_{2}$ was commonly used in air conditioning and marine refrigeration as a working fluid, for it is not expensive and widely available [32], [33]. Therefore, instead of looking to $\mathrm{CO}_{2}$ as a part of the problem causing a greenhouse effect, it could be considered a solution for thermal mass in a lightweight structure.

Low-carbon city [34] could consider low-carbon production and consumption in order to accomplish lower energy consumption and reduce $\mathrm{CO}_{2}$ emission [35]. $\mathrm{CO}_{2}$ can be extracted from combustion emission by available techniques, like conventional wet scrubbing and Amine scrubbing, then it can be reused in other ways [36]. A thermal-floor offers a good option for $\mathrm{CO}_{2}$ to work as a thermal fluid causing a micro greenhouse effect within the floor and reducing heat demand; instead of releasing $\mathrm{CO}_{2}$ to the atmosphere or injecting it in geological reservoirs. Table 2 summarises all the results discussed in this study.

TABle 2. Results Summary, Thermal-Floor Performance In Subtopic Climate, AMMAN, JORDAN LOCATION

\begin{tabular}{|c|c|c|}
\hline $\begin{array}{l}\text { Passive design } \\
\text { techniques }\end{array}$ & With thermal-floor & Without thermal-floor \\
\hline $\begin{array}{l}\text { Window to wall } \\
\text { ratio }\end{array}$ & $\begin{array}{l}\text { Increasing the ratio from } 20 \% \text { to } 80 \% \\
\text { reduces the Heating demand by } \\
18 \mathrm{kWh} / \mathrm{m}^{2} \text { per year. }\end{array}$ & $\begin{array}{l}\text { Increasing the ratio from } 20 \% \text { to } 80 \% \\
\text { reduces the Heating demand by } 6.5 \% \text { only. }\end{array}$ \\
\hline $\begin{array}{l}\text { Subfloor vs. } \\
\text { floor on the } \\
\text { ground }\end{array}$ & $\begin{array}{l}\text { Thermal-floor combined with subfloor } \\
\text { (floor elevated from the ground) reduces } \\
\text { the heating demand by } 27 \mathrm{kWh} / \mathrm{m}^{2} \text { per } \\
\text { year. }\end{array}$ & $\begin{array}{l}\text { Subfloor only reduces the heating demand by } \\
7 \mathrm{kWh} / \mathrm{m}^{2} \text { per year. }\end{array}$ \\
\hline $\begin{array}{l}\text { Thermal mass } \\
\text { Material (cover } \\
25 \% \text { of floor } \\
\text { area) }\end{array}$ & \multicolumn{2}{|c|}{$\begin{array}{l}\text { Both PMJ and } \mathrm{CO}_{2} \text { gas (at } 100 \mathrm{kPa} \text { ) reduced the energy demand for heating by } 50 \% \\
\text { compared to concrete. PMJ reduced the heating demand by } 31 \mathrm{kWh} / \mathrm{m}^{2} \text { per year when } \\
\text { compared to insulated tiles and by } 29 \mathrm{kWh} / \mathrm{m}^{2} \text { per year compared to a } 20 \mathrm{~cm} \text { concrete slab } \\
\text { floor. } \mathrm{CO}_{2} \text { reduced the heating demand by } 85 \mathrm{kWh} / \mathrm{m}^{2} \text { per year compared to a } 20 \mathrm{~cm} \\
\text { concrete slab floor. }\end{array}$} \\
\hline $\begin{array}{l}\text { Area of thermal- } \\
\text { floor }\end{array}$ & \multicolumn{2}{|c|}{$\begin{array}{l}\text { Increasing the thermal-floor area from } 25 \% \text { to } 100 \% \text { of the total shelter area reduced the } \\
\text { Heating demand by only } 3 \mathrm{kWh} / \mathrm{m}^{2} \text { per year; it has an effect because only a certain part of } \\
\text { the floor is subjected to the solar radiation coming from the southern window and this part } \\
\text { will function as a thermal storage. }\end{array}$} \\
\hline $\begin{array}{l}\text { Internal vs. } \\
\text { external thermal } \\
\text { mass }\end{array}$ & \multicolumn{2}{|c|}{$\begin{array}{l}\text { Internal mass, whether it is a wall or floor reduces Heating demand. An internal wall of } \\
(\mathrm{PMJ}) \text { reduces Heating demand by } 4 \mathrm{kWh} / \mathrm{m}^{2} \text { per year compared to the external wall of } \\
(\mathrm{PMJ}) \text {, and (PMJ) floor reduces the Heating demand by } 11 \mathrm{kWh} / \mathrm{m}^{2} \text { per year compared with } \\
\text { the external wall of (PMJ). Considering the wall or the floor to be entirely covered with } \\
(\mathrm{PMJ}) \text {. }\end{array}$} \\
\hline
\end{tabular}




\section{Conclusion}

This research investigates the thermal mass for a prefabricated lightweight shelter by replacing the traditional thermal mass with lighter materials, hence PCM and $\mathrm{CO}_{2}$ Hvacloadexplorer software validated by experimental data is used to improve thermal comfort in lightweight shelters with PCM for different climate zones. Results showed that PCM could effectively control the indoor temperature rise and temperature fluctuations. The most favorable results were achieved when PMJ was used in the thermal-floor in a $20 \mathrm{~cm}$ thick subfloor covering $25 \%$ of the total floor area of the shelter model. Southern facing windows, covering $40 \%$ of the wall area, were utilized to capture the winter's solar radiation. Initially, the thermalfloor was investigated for the four main climate zones: tropic, subtropics (arid regions), temperate, and cold. Evaluating the performance of the shelter's model in temperate climates, such as London, UK, the thermal-floor reduced heating demand by $13 \mathrm{kWh} / \mathrm{m}^{2}$ per year. The thermal-floor did not work efficiently in polar cold regions, which could be attributed to the very low temperature and low solar radiation angles. Yet, for the tropical hot humid climate with warm winters, the thermal-floor had a negative effect and caused overheating creating an oven effect over many hot days. However, arid regions were the best zones for a thermal-floor with high solar insolation and cold winters. PCM and $\mathrm{CO}_{2}$ floors reduced the heating load by 40-50 \% given the diurnal temperature ranges between day and night. Both $\mathrm{PMJ}$ and $\mathrm{CO}_{2}$ gas reduced the heating energy demand for heating by $65-85 \mathrm{kWh} / \mathrm{m}^{2}$ per year compared to concrete. PMJ reduced the heat demand by $31 \mathrm{kWh} / \mathrm{m}^{2}$ compared to insulated tiles, and by $56 \mathrm{kWh} / \mathrm{m}^{2}$ compared to concrete. $\mathrm{CO}_{2}$ reduced the heating demand by $85 \mathrm{kWh} / \mathrm{m}^{2}$ compared to a $20 \mathrm{~cm}$ concrete slab floor. When the thermal-floor was combined with subfloor (floor elevated from the ground), it reduced the heating demand by $27 \mathrm{kWh} / \mathrm{m}^{2}$. Internal mass whether it was a wall or a floor reduced the heating load, which is based on the building's heat losses. PMJ internal wall reduced heat demand by $4 \mathrm{kWh} / \mathrm{m}^{2}$ and PMJ floor by $11 \mathrm{kWh} / \mathrm{m}^{2}$ compared to the external wall of PMJ. Increasing window to wall ratio from $20 \%$ to $80 \%$ reduced the heating demand by $7 \mathrm{kWh} / \mathrm{m}^{2}$ only but when combined with internal thermal mass (thermalfloor), under the same ratio, the heating demand was reduced by $22 \mathrm{kWh} / \mathrm{m}^{2}$.

\section{REFERENCES}

[1] Hassan W. H., Alkhalidi A. Comparing Between Best Energy Efficient Techniques Worldwide with Existing Solution Implemented in Al-Ahliyya Amman University. International Journal of Thermal and Environmental Engineering 2018:17(1):1-10. https://doi.org/10.5383/ijtee.17.01.001

[2] Verbeke S., Audenaert A. Thermal inertia in buildings: A review of impacts across climate and building use. Renewable and Sustainable Energy Reviews 2018:82(3):2300-2318. https://doi.org/10.1016/j.rser.2017.08.083

[3] Royal Scientific Society. Green Building Development in Jordan, 2012.

[4] Popp D. International technology transfer, climate change, and the clean development mechanism. Review of Environmental Economics and Policy 2011:5(1):131-152. https://doi.org/10.1093/reep/req018

[5] Yang L., Li Y. Cooling load reduction by using thermal mass and night ventilation. Energy and Building 2008:40(11):2052-2058. https://doi.org/10.1016/j.enbuild.2008.05.014

[6] Hampton A. Thermal Mass and Insulation for Temperate Climates. Environment Design Guide. 2010:1-11.

[7] Reilly A., Kinnane O. The impact of thermal mass on building energy consumption. Applied Energy 2017:198:108121. https://doi.org/10.1016/j.apenergy.2017.04.024

[8] Navarro L. et al. Thermal energy storage in building integrated thermal systems: A review. Part 1. active storage systems. Renewable Energy 2016:88:526-547. https://doi.org/10.1016/j.renene.2015.11.040

[9] Wan Omar W. M. S., Doh J.-H., Panuwatwanich K., Miller D. Assessment of the embodied carbon in precast concrete wall panels using a hybrid life cycle assessment approach in Malaysia. Sustainable Cities and Society 2014:10:101111. https://doi.org/10.1016/j.scs.2013.06.002 
[10] Zalba B., Marin J. M., Cabeza L. F., Mehling H. Review on thermal energy storage with phase change: materials, heat transfer analysis and applications. Applied Thermal Engineering 2003:23(3):251-283. https://doi.org/10.1016/s13594311(02)00192-8

[11] Al-Tamimi N. A., Fadzil S. F. S. The potential of shading devices for temperature reduction in high-rise residential buildings in the tropics. Procedia Engineering 2011:21:273-282. https://doi.org/10.1016/j.proeng.2011.11.2015

[12] Hermelink A. et al. Towards nearly zero- energy buildings Definition of common principles under the EPBD Final report Towards nearly zero-energy buildings Definition of common principles under the EPBD, 2012.

[13] Maragogiannis K., Kolokotsa D., Maria E. A. Study of Night Ventilation Efficiency in Urban Environment: Technical and Legal Aspects. Environmental and Climate Technologies 2011:6(1):46-56. https://doi.org/10.2478/v10145-0110007-1

[14] Meir I. A., Roaf S. C. Thermal comfort-thermal mass: housing in hot dry climates. Proc. $9^{\text {th }}$ Int. Conf. on Indoor air quality and climate (ed. H. Levin), vol. 1, 2002.

[15] Siddiqui O., Kumar R., Fung A. S., Zhang D., White M. A., Whitman C. A. Modelling for performance prediction of highly insulated buildings with different types of thermal mass. Applied Thermal Engineering 2017:122:139-147. https://doi.org/10.1016/j.applthermaleng.2017.05.021

[16] Alkhalidi A., Jarad H., Juaidy M. Glass Properties Selection Effect on LEED Points for Core and Shell High Rise Residential Building in Jordan. Int. J. Therm. Environ. Eng., 2016:13(1):29-35. http://iasks.org/wpcontent/uploads/pdf/IJTEE-1301006.pdf

[17] Alkhalidi A., Kiwan S., Hamasha H. A Comparative Study Between Jordanian Overall Heat Transfer Coefficient (UValue) and International Building Codes. 10 ${ }^{\text {th }}$ Int. Renewable Energy Congress (IREC), Sousse, Tunisia, 2019. https://doi.org/10.1109/IREC.2019.8754639

[18] Taheri H., Sharma A. An overview of phase change materials for building applications. Green Energy Technologies 2015:201:189-213. https://doi.org/10.1007/978-81-322-2337-5_8

[19] The Chartered Institution of Building Services Engineers. The limits of thermal comfort : avoiding overheating in European buildings, 2013.

[20] McQuiston F. C. Parker J. D. Heating, Ventiling and Air Conditioning, Analysis and Design. New York: John Wiley \& Sons, 1994.

[21] Jawarneh A. M., Al-Shyyab A. S. Potential of Solar Energy in Zarqa Region. International Scholarly and Scientific Research and Innovation 2011:5(4):523-527.

[22] Mukherjee R., Memik S. O. Systematic temperature sensor allocation and placement for microprocessors. Presented at $43^{\text {rd }}$ Annual Design Automation Conference, San Francisco, USA, 2006. https://doi.org/10.1145/1146909.1147051

[23] Huynh T. Fundamentals of Thermal Sensors. In: Jha C. (eds) Thermal Sensors. New York: Springer, pp. 5-42, 2015. https://link.springer.com/chapter/10.1007/978-1-4939-2581-0_2

[24] Rao Z. H., Zhang G. Q. Thermal properties of paraffin wax-based composites containing graphite. Energy Sources, Part A: Recovery, Utilization and Environmental Effects 2011:33(7):587-593. https://doi.org/10.1080/15567030903117679

[25] Elsafty A. F., Joumaa C., Abo Elazm M. M., Elharidi A. M. Case study analysis for building envelop and its effect on environment. Energy Procedia 2013:36:958-966. https://doi.org/10.1016/j.egypro.2013.07.109

[26] Elsafty A., Saeid L. Sea water air conditioning: A cost effective alternative. International Journal of Engineering 2009:3(3):346-358.

[27] McQuiston F. C., Parker J. D., Spitler J. D. Heating, Ventilating, and Air Conditioning Analysis and Design, New York: John Wiley \& Sons, 2005.

[28] ASHRAE. 2005 ASHRAE Handbook: Fundamentals. ASHRAE, 2005.

[29] Kolokotroni M., Davies M., Croxford B., Bhuiyan S., Mavrogianni A. A validated methodology for the prediction of heating and cooling energy demand for buildings within the Urban Heat Island: Case-study of London. Solar Energy 2010:84(12):2246-2255. https://doi.org/10.1016/j.solener.2010.08.002

[30] Boduch M., Fincher W. Standards of human comfort. Center for Sustainable Development, pages 1-9, 2009. https://www.scribd.com/document/410985071/1-Boduch-Fincher-Standards-of-Human-Comfort

[31] Neksa P., Rekstad H., Zakeri G. R. Schiefloe P. A. $\mathrm{CO}_{2}$-heat pump water heater: characteristics, system design and experimental results. International Journal of Refrigeration 1998:21(3):172-179. https://doi.org/10.1016/S01407007(98)00017-6

[32] Slee B., Parkinson T., Hyde R. Quantifying useful thermal mass: How much thermal mass do you need? Architectural Science Review 2014:57(4):271-285. https://doi.org/10.1080/00038628.2014.951312

[33] Franklin Associates. Cradle-to-gate life cycle inventory of nine plastic resins and four polyurethane precursors. A Division of Eastern Research Group, Inc. 2010:1(1):572.

[34] Alkhalidi A., Qoaider L., Khashman A., Al-Alami A. R., Jiryes S. Energy and water as indicators for sustainable city site selection and design in Jordan using smart grid. Sustainable Cities and Society 2018:37:125-137. https://doi.org/10.1016/j.scs.2017.10.037

[35] Yang L., Li Y. Low-carbon city in China. Sustainable Cities and Society 2013:9:62-66. https://doi.org/10.1016/j.scs.2013.03.001 
[36] Yeh J. T., Pennline H. W., Resnik K. P. Study of $\mathrm{CO}_{2}$ Absorption and Desorption in a Packed Column. Energy \& Fuels 2001:15(2):274-278. https://doi.org/10.1021/ef0002389
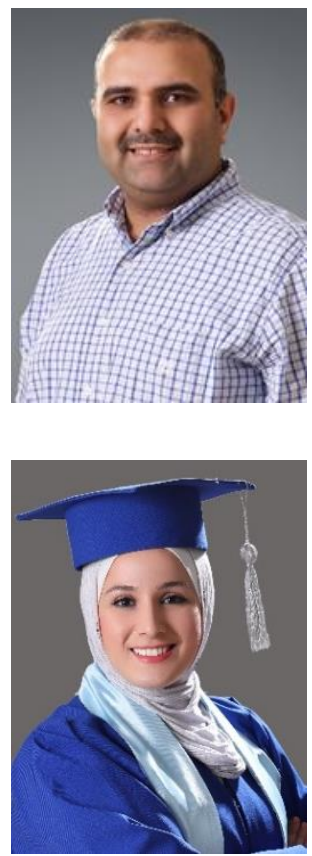

Dr. Ammar Alkhalidi is an associate professor in the Energy Engineering Department at German Jordanian University since January 2014. He received the Ph.D. degree in mechanical engineering from the University of Wisconsin Milwaukee in 2011. Masters and Bachelor degrees in mechanical engineering were received from the University of Jordan in 2006 and 2004 respectively.

During Ph.D. research, Dr. Alkhalidi investigated energy savings in wastewater in air diffusers manufactured by ITT Sanitaire. The results of this project were patented by UWM and ITT. Dr. Alkhalidi has worked on several projects, including the Energy Efficiency and Renewable Energy in Jordanian Water Sector.

Dr. Alkhalidi published more than 30 journal papers and 27 Conference Paper. Paper topics distributed between microfluidic, Heat Transfer, Building envelop and Hydroponics. See the ResearchGate for more paper details.

ORCID iD: http://orcid.org/0000-0002-3501-2664

Arch. Yara Nidal Zaytoun is a freelance architect with a master's degree in environmental and renewable energy engineering from German Jordanian university GJU 2018. Bachelor degree in architectural engineering was received from Palestine Polytechnic University PPU, as an honoured student top of her class 2012.

During master's research, Arch. Zaytoun focused on creating a sustainable shelter for refugee camps. The shelter design combined an off-grid PV cells with passive design such as thermal mass, southern windows and thermal insulation generate passive solar gains which resulted in reducing the heating energy demand by 30-40\%. Throughout the course of her architectural design, implementing energy efficiency and passive design techniques was her priority. 